\title{
Phytoalexins and signalling metabolites produced in the wild crucifer Neslia paniculata: camalexins and arabidopsides
}

\author{
M. Soledade C. Pedras, ${ }^{*}$ Mahla Alavi and Abbas Abdoli \\ Department of Chemistry, University of Saskatchewan, 110 Science Place, \\ Saskatoon, SK, S7N 5C9 \\ Canada
}

Corresponding author: M. Soledade C. Pedras

ORCID: $\quad$ 0000-0002-9510-2215

Email: s.pedras@usask.ca

Telephone: 1-306-966-4772 


\section{Phytoalexins and signalling metabolites produced in the wild crucifer Neslia paniculata: camalexins and arabidopsides}

\section{Graphical abstract}

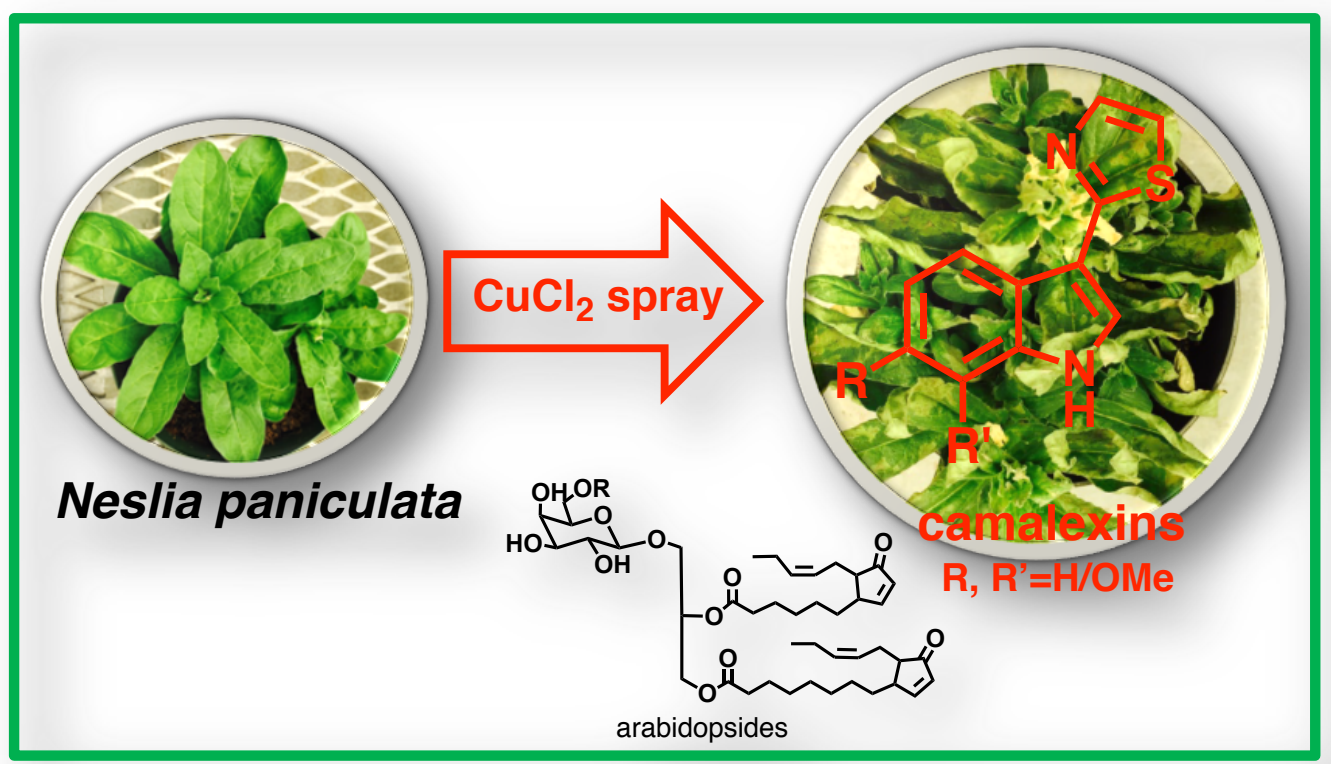

\section{Abstract}

The metabolites produced in elicited leaves of the wild crucifer Neslia paniculata (L.) Desv. were investigated in abiotically stressed plants. Herein the phytoalexins camalexin, 7-methoxycamalexin and 6,7-dimethoxycamalexin together with the signalling metabolites arabidopsides $A$ and $D$ are reported. This is the first report of occurrence of 7-methoxy and 6,7-dimethoxycamalexins in planta and the third example of synchronized biosynthesis of phytoalexins and galacto-oxylipins. It is suggested that arabidopsides and structurally similar metabolites functioning as signalling molecules are likely to occur in a much larger number of plant species than originally hypothesized. N. paniculata is potentially useful to generate hybrid plants resistant to blackleg disease caused by Leptosphaeria maculans.

Keywords: 7-methoxycamalexin; 6,7-dimethoxycamalexin; Alternaria brassicicola; arabidopsides; Brassicaceae; camalexin; crucifer; galacto-oxylipins; Leptosphaeria maculans; Neslia paniculata. 


\section{Introduction}

Neslia paniculata (L.) Desv. is a wild crucifer (common name ball mustard, family Brassicaceae) in the order Brassicales and a close relative of species that belong to the tribe Camelineae (e.g., Arabidopsis thaliana L. Heynh., Camelina sativa L., Capsella bursa-pastoris L.) (The Plant List, http://www.theplantlist.org/1/). Crucifers include a broad range of economically important species, from worldwide cultivated oilseeds, such as canola (Brassica napus L., B. rapa L.) and rapeseed (B. napus, B. rapa), to vegetables like cauliflower (Brassica oleracea var. botrytis L.) and broccoli (Brassica oleracea var. italica Plenck), and condiments such as wasabi (Eutrema wasabi Maxim.). N. paniculata co-exists with various crops, including canola and condiment mustard (B. juncea L.), causing seed contamination problems due to its abundance. Despite such a drawback, N. paniculata, the only known species within the genus Neslia, is of interest as a source of disease resistance genes to Alternaria black spot, a plant disease caused by Alternaria species (Francis and Warwick, 2003; Tewari and Conn, 1993).

Most intriguingly, unlike many crucifers, N. paniculata produces glucosinolates (GLs) in seeds but not in leaves (Kjaer and Schuster, 1972; Windsor et al., 2005). In fact, a detailed investigation of GL production in organs of plant species in a subclade of the tribe Camelineae confirmed that $N$. paniculata does not produce GLs in leaves (Czerniawski et al., 2021). Glucosinolates are constitutive plant metabolites produced only in species of the order Brassicales (Agerbirk and Olsen, 2012; Blazevic et al., 2020). GLs contain a functional group composed of an O-sulfated thiohydroximate connected to a $\beta$-glucopyranosyl residue through a sulfur atom and are biosynthesized from a narrow range of amino acids. GLs and their metabolic products have important ecological functions that contribute to plant resistance to pests and diseases (Agerbirk and Olsen, 2012; Blazevic et al., 2020; Pastorczyk and Bednarek, 2016).

Unlike GLs, phytoalexins are elicited (i.e., not constitutive) plant metabolites with antimicrobial activity, produced de novo in response to stress, including pathogen attack, heavy metal salts or UV radiation (Bailey and Mansfield, 1982; Kúc, 1995; VanEtten et al., 1994). Undeniably, phytoalexins are crucial components of plant defense programs against microbial pathogens (Ahmed and Kovinich, 2020). Brassicales species, and in particular Brassicaceae species, produce unique arrays of phytoalexins with $S, N$-containing structures that are mostly derived from either $(S)$-Trp, via 3methylindolyl GL (7) and methoxy derivatives, or (S)-Phe via benzyl GL (8) and hydroxy/methoxy derivatives (Pedras et al., 2011; Pedras and To, 2015, 2016). The similarity among the chemical transformations occurring in phytoalexin pathways of Brassicales species suggests an evolutionary conservation of biosynthetic enzymes (Pedras and Alavi, 2020). Furthermore, a striking correlation among the chemical structures of phytoalexins within selected groups of plant species led us to suggest 
that species in phylogenetically related tribes produce structurally similar and/or identical phytoalexins (Pedras and Alavi, 2020). For example, (i) brassinins 1 and 2 are produced in various species of the tribe Brassiceae, (ii) wasalexins A (3) and B (4) are produced in species of the closely related tribes Thlaspideae (Thlaspi arvense L.) and Eutremeae (Thellungiella salsuginea (Pall.) O.E. Schulz), (iii) nasturlexins $\mathbf{5}$ and $\mathbf{6}$ are produced in species of the tribe Cardamineae, and (iv) camalexins $\mathbf{9}$ and 10 are produced in species of the tribe Camelineae, (Pedras et al, 2011; Pedras et al., 2015). Hence, it is of enormous interest to investigate the phytoalexin profile of $N$. paniculata. Here we report the phytoalexins and additional elicited metabolites produced in elicited leaves of $N$. paniculata.
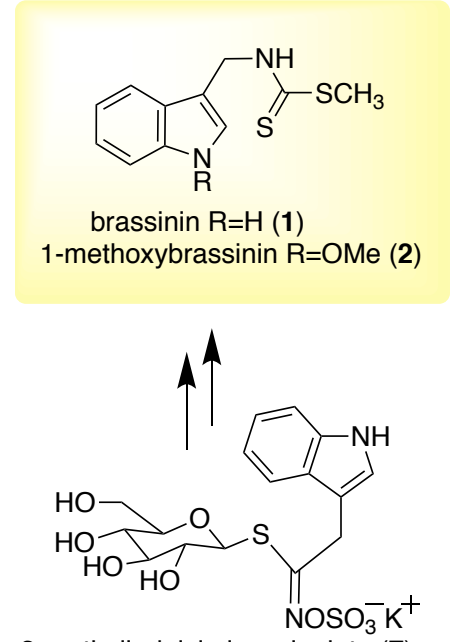

3-methylindolyl glucosinolate (7)

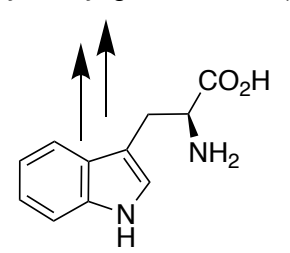

(S)-Trp
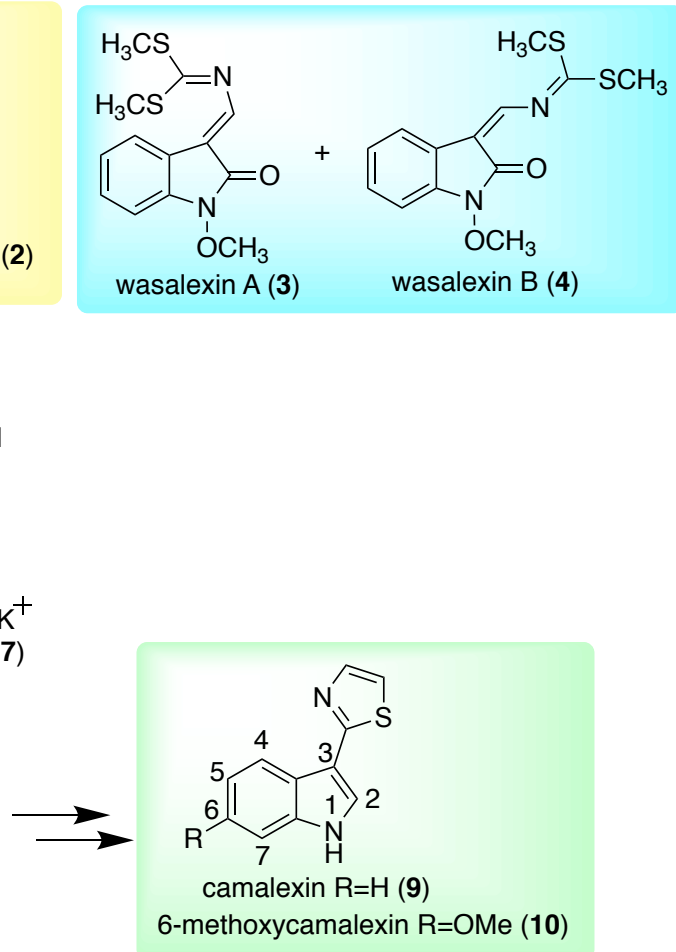
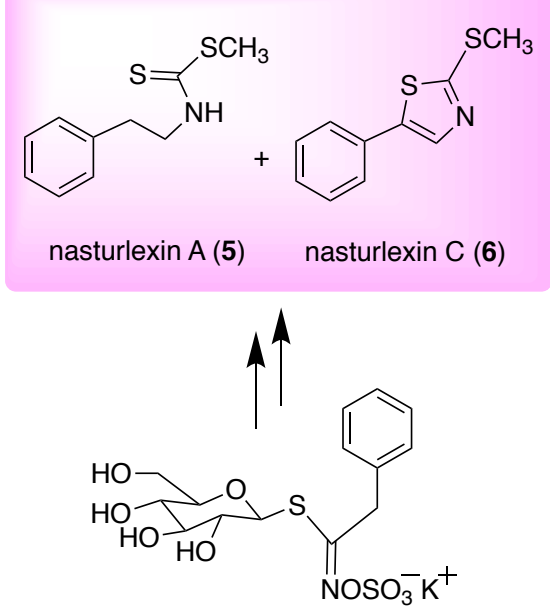

benzyl glucosinolate (8)

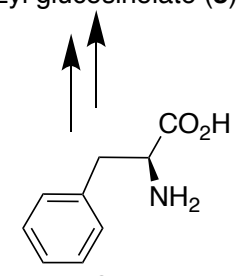

(S)-Phe

Fig. 1. Selected cruciferous phytoalexins 1-6, 9 and 10, precursors (S)-Trp, (S)-Phe and glucosinolates (GLs) 7 and 8. 


\section{Results}

\subsection{Detection, isolation, structure elucidation and quantification of elicited metabolites}

Seeds of $N$. paniculata were germinated in Petrie dishes and then transplanted to a potted soil mixture as described in the Experimental. Leaves of 4-week-old plants were elicited (aq. $\mathrm{CuCl}_{2}$ spray), harvested at different times, immediately frozen in liquid nitrogen and extracted as detailed in Section 4.3. Control plants (non-elicited) were treated similarly. The leaf extracts of $\mathrm{CuCl}_{2}$ - elicited and control plants were analyzed by HPLC-DAD-ESI-MS to uncover elicited metabolites (Fig. 2). Comparison of the HPLC-DAD profiles of extracts of elicited leaves with those of controls showed the presence of several peaks (at $t_{R}=10.4,13.4,13.7,15.1,26.3,28.9$ and $33.4 \mathrm{~min}$ ) not detected in extracts of control leaves (Alavi, 2019).

\subsubsection{Indolyl metabolites $\left(t_{R}=10.4,13.4,13.7,15.1\right)$}

The metabolites at $t_{\mathrm{R}}=10.4$ and $13.7 \mathrm{~min}$ were identified as methyl indolyl-3-carboxylate (13) and camalexin (9), respectively, by direct comparison with synthetic samples (HPLC- $t_{R}$, UV and MS data) and confirmed by chemical syntheses. Data for the peaks at $t_{R}=13.4$ and 15.1 min available in our HPLC metabolite libraries were not conclusive, although a similarity to the UV spectrum of camalexin (9) was noted. These compounds were isolated after fractionation of larger amounts of extracts of elicited leaves (chromatogram in Fig. S1), as described in Section 4.4. Their chemical structures were established by analyses of spectroscopic data, as described below $\left(t_{R}=13.4,12 ; 15.1 \mathrm{~min}, 11\right)$ and confirmed by chemical syntheses (Pedras and Abdoli, 2018).

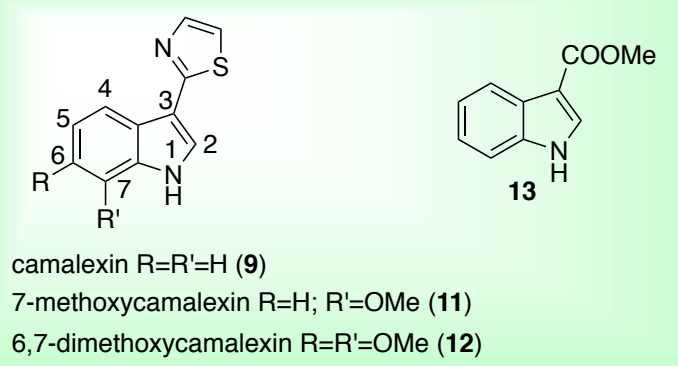



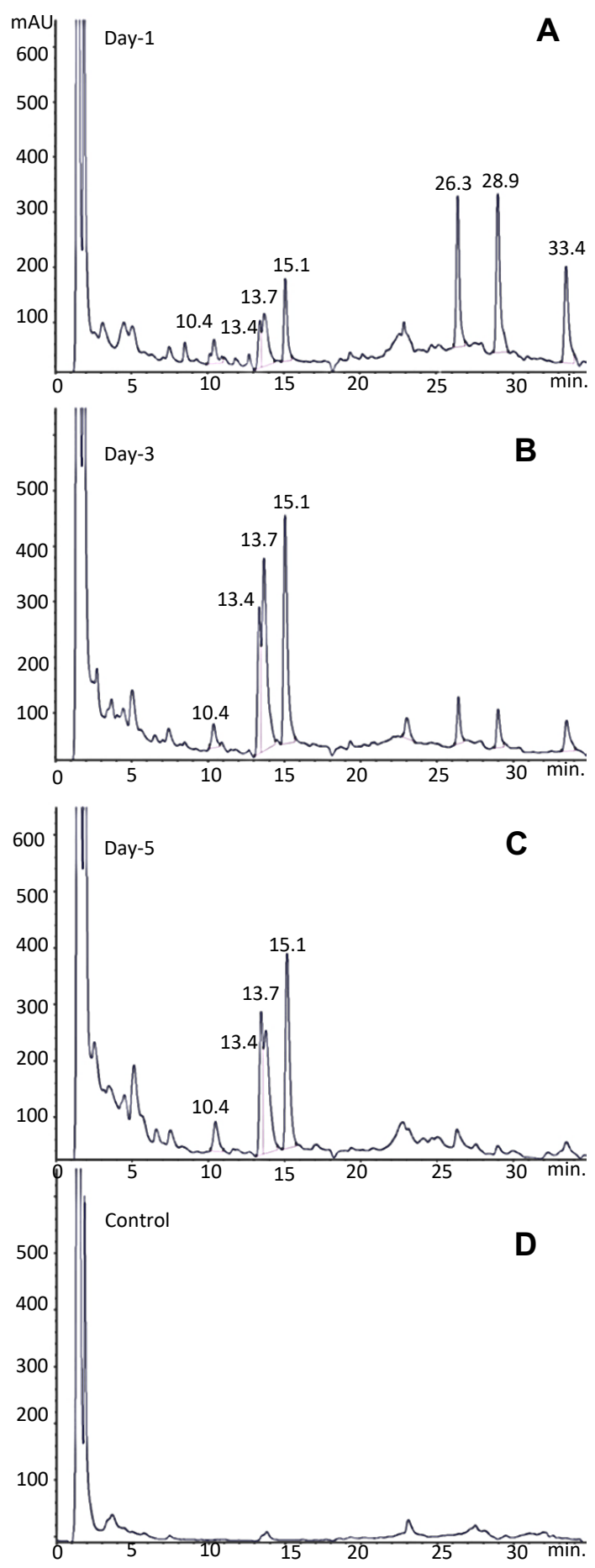

Fig. 2. HPLC-DAD chromatograms (method A, $220 \mathrm{~nm}$ ) of extracts of elicited leaves of Neslia paniculata: A, 24 h post-elicitation; B, $72 \mathrm{~h}$ post-elicitation; C, $120 \mathrm{~h}$ post-elicitation; D extracts of non-elicited leaves (control). Peaks identified: $t_{\mathrm{R}}=10.4 \mathrm{~min}$, methyl indolyl-3-carboxylate $(13) ; t_{\mathrm{R}}=13.7$ min, camalexin (9); $t_{R}=13.4 \mathrm{~min}, 6,7$-dimethoxycamalexin (12); $t_{R}=15.1 \mathrm{~min}$, 7methoxycamalexin (11); $t_{R}=26.3 \mathrm{~min}$, arabidopside $\mathrm{D}(15) ; t_{\mathrm{R}}=28.9 \mathrm{~min}$, arabidopside $A$ (14); $t_{\mathrm{R}}=33.4 \mathrm{~min}$, unidentified arabidopside. 
Table 1. HPLC-DAD time-course analyses of metabolite production in leaves of Neslia paniculata (method A, detection at $220 \mathrm{~nm}$ ).

\begin{tabular}{l|l|l}
\hline Metabolite (\#) (tR min) & Incubation time (h) & $\begin{array}{l}\text { Amount }(\mu \mathrm{mol} / 100 \mathrm{~g} \text { of } \\
\text { fresh tissue } \pm \text { standard } \\
\text { deviation) }\end{array}$ \\
\hline Camalexin (9) (13.7 min) $^{\mathrm{b}}$ & 24 & $\leq 9$ \\
& 72 & $\leq 18$ \\
& 120 & $\leq 15$ \\
\hline 7-Methoxycamalexin (11) & 24 & $5 \pm 1$ \\
(15.1 min) & 72 & $15 \pm 3$ \\
& 120 & $13 \pm 1$ \\
\hline 6,7-Dimethoxycamalexin (12) (13.4 & 24 & $\leq 11$ \\
min) & 72 & $\leq 21$ \\
& 120 & $\leq 18$ \\
\hline Methyl 3-indolecarboxylate (10.4 & 24 & $1 \pm 0$ \\
min) (13) & 72 & $1 \pm 0$ \\
& 120 & \\
\hline
\end{tabular}

${ }^{a}$ Average of triplicate samples \pm standard deviations.

${ }^{b}$ Quantification is not accurate due to partial overlap of peaks of 6,7-dimethoxycamalexin (12) and camalexin (9).

The UV spectrum of the metabolite at $t_{R}=15.1 \mathrm{~min}$ was similar to that of camalexin (9) and the HR-El-MS data showed a quasi-molecular ion at $\mathrm{m} / \mathrm{z}[\mathrm{M}]^{+} 230.0509$, consistent with the molecular formula $\mathrm{C}_{12} \mathrm{H}_{10} \mathrm{~N}_{2} \mathrm{OS}$ (nine unsaturations and an additional $\mathrm{CH}_{2} \mathrm{O}$ unit relative to the molecular formula of 9, $\left.\mathrm{C}_{11} \mathrm{H}_{8} \mathrm{~N}_{2} \mathrm{~S}\right)$. The ${ }^{1} \mathrm{H}$ NMR spectroscopic data $\left(\mathrm{CD}_{3} \mathrm{CN}\right)$ was consistent with the molecular formula, showing signals for 10 protons that included a singlet (methoxyl, $\delta 3.97, \mathrm{~s}, 3 \mathrm{H}$ ) and two doublets at $\delta_{\mathrm{H}}$ 7.35 and $7.77(\mathrm{~J}=3 \mathrm{~Hz})$ that were consistent with adjacent protons of a thiazolyl ring (SI). Furthermore, the coupling constants of the signals at $\mathrm{d} 7.80(\mathrm{~d}, 1 \mathrm{H}, \mathrm{J}=8 \mathrm{~Hz}) 7.17(\mathrm{dd}, 1 \mathrm{H}, \mathrm{J}=8,8 \mathrm{~Hz})$, and $6.79(\mathrm{~d}$, $1 \mathrm{H}, J=8 \mathrm{~Hz}$ ) indicated that the methoxyl group was attached to either $\mathrm{C}-4$ or $\mathrm{C}-7$ of the indole ring. That is, the structure of the metabolite at $t_{R}=15.1 \mathrm{~min}$ could be either 4-methoxycamalexin or 7methoxycamalexin. Comparison of the HPLC data and ${ }^{1} \mathrm{H}$ NMR spectroscopic data of the isolated metabolite with those of a synthetic sample (Alavi, 2019; Pedras and Abdoli, 2018) demonstrated that the isolated metabolite was 7-methoxycamalexin (11) (SI).

Similarly, the UV spectrum of the metabolite at $t_{R}=13.4$ min resembled that of camalexin (9) and the ESI-MS data showed ions at $m / z 258.8$ [M-1] $]^{-}$and $m / z 260.9[\mathrm{M}+1]^{+}(\mathrm{SI})$. The ${ }^{1} \mathrm{H}$ NMR spectrum displayed signals of 12 protons and indicated that this compound was a dimethoxy substituted camalexin. The coupling pattern of the indole ring protons at $\delta 7.87(\mathrm{dd}, 1 \mathrm{H}, J=8.5 \mathrm{~Hz}$ ) and 7.03 (dd, $1 \mathrm{H}, J=8.5 \mathrm{~Hz})$ suggested that the two methoxyl groups $(\delta 3.94, \mathrm{~s}, 3 \mathrm{H}$ and $\delta 3.90 \mathrm{~s}, 3 \mathrm{H})$ were attached to either C-4 and C-5, or C-4 and C-7, or C-6 and C-7. That is, based on this analysis the structure of 
this metabolite could be 4,5-dimethoxycamalexin, 4,7-dimethoxycamalexin or 6,7-dimethoxycamalexin. Comparison of HPLC data and ${ }^{1} \mathrm{H}$ NMR spectroscopic data of the isolated metabolite with those of a synthetic sample (Pedras and Abdoli, 2018) demonstrated that the isolated metabolite was 6,7dimethoxycamalexin (12).

\subsubsection{Non-indolyl metabolites $\left(t_{R}=26.3,28.9\right.$ and $\left.33.4 \mathrm{~min}\right)$}

The UV spectra $\left(\lambda_{\max } 220 \mathrm{~nm}\right.$, due to the presence of an $\alpha, \beta$-unsaturated ketone, Fig. S2) of peaks at $t_{R}=26.3,28.9$ and 33.4 min were identical to the UV spectra of arabidopsides $A(14)$ and D (15) (Pedras and To, 2017). Furthermore, the HPLC-ESI-MS (positive mode) spectra showed fragment ions at $\mathrm{m} / \mathrm{z} 641.4(100 \%)$ for the metabolite at $t_{R}=26.3 \mathrm{~min}$, and at $\mathrm{m} / \mathrm{z} 613.2(100 \%)$ for the metabolite at $t_{R}=28.9 \mathrm{~min}$, suggesting these metabolites to be arabidopsides $D(15)$ and $A(14)$, respectively. As well, these retention times $\left(t_{R}=26.3\right.$ and $28.9 \mathrm{~min}$ ) were consistent with those previously reported for arabidopsides D (15) and A (14) (using identical elution methods as reported in Pedras and To, 2017); however, the compound with $t_{R}=33.4 \mathrm{~min}$ was not available in our metabolite libraries. Nonetheless, considering the similarity of the UV absorption spectra $\left(\lambda_{\max } 220 \mathrm{~nm}\right)$ of compound with $t_{R}=33.4 \mathrm{~min}$ and arabidopsides $A$ and $D$, we suggest that this metabolite has an arabidopside type structure as well (Hisamatsu et al., 2003, 2005; Genva et al., 2019).

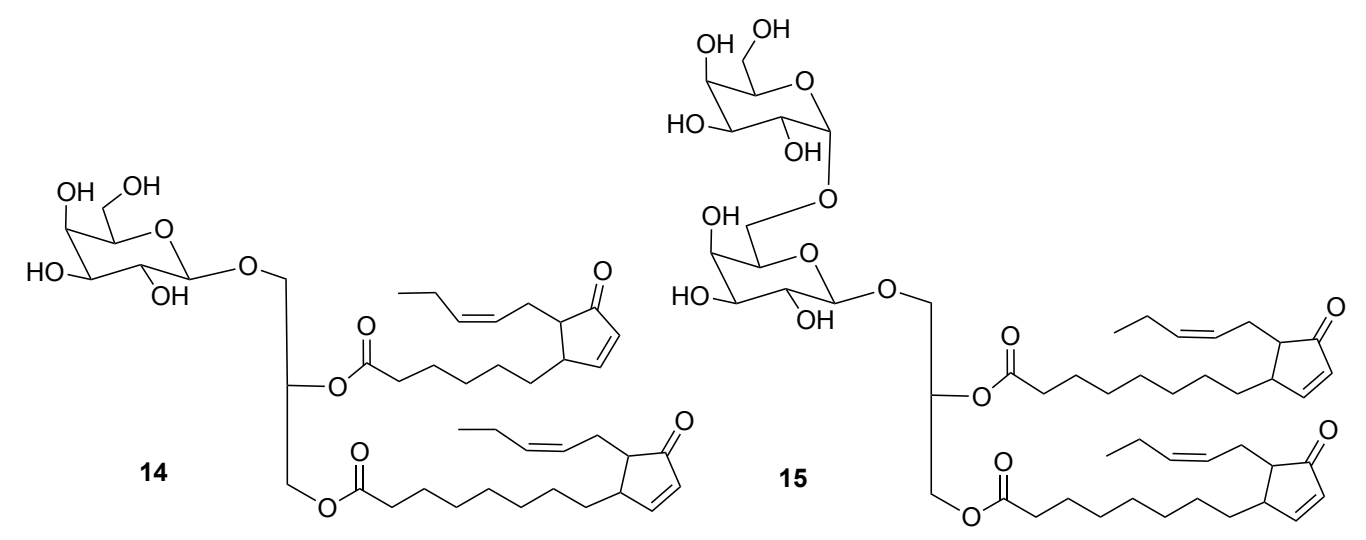

The peak areas of compounds eluting at $t_{R}=26.3,28.9$ and $33.4 \mathrm{~min}$ in the HPLC chromatograms shown in Fig. 1 showed a sharp decrease one day after elicitation; five days after elicitation the peaks of these compounds were undetectable (Alavi, 2019). That is, while camalexin production increased one day after elicitation and remained well above detection levels for five days, the production of arabidopsides decreased substantially. 


\subsection{Antifungal activity of camalexin (9) and methoxycamalexins 11 and 12}

The antifungal activities of camalexins produced by $N$. paniculata were tested using a fungal radial growth assay, against three phytopathogenic fungal species: Alternaria brassicicola (Schwein.) Wiltshire and Leptosphaeria maculans (Desm.) Ces. et de Not. [asexual stage Phoma lingam (Tode ex Fr.) Desm., both specific pathogens of Brassica species, and Sclerotinia sclerotiorum (Lib.) de Bary, a generalist plant pathogen that infects numerous plant species including Brassicales species (Pedras et al., 2015). Camalexin (9) displayed the highest inhibitory activity against $A$. brassicicola and $S$. sclerotiorum, causing complete mycelial growth inhibition at 0.25 and $0.10 \mathrm{mM}$, respectively, whereas 7- methoxycamalexin (11) was more inhibitory to L. maculans (causing complete mycelial growth inhibition at $0.25 \mathrm{mM}$ ); 6,7-dimethoxycamalexin (12) displayed the lowest inhibitory activity on all species causing only complete growth inhibition of S. sclerotiorum at $0.50 \mathrm{mM}$ (Alavi, 2019).

Table 2. Antifungal activity of elicited metabolites of Neslia paniculata against the fungal pathogens Alternaria brassicicola, Leptosphaeria maculans, and Sclerotinia sclerotiorum.

\begin{tabular}{l|l|l|l} 
Compound & \multicolumn{3}{|c}{$\%$ Inhibition \pm standard deviation } \\
\hline & A. brassicicola & L. maculans & S. sclerotiorum \\
\hline Camalexin (9) & $100 \pm 0$ & $100 \pm 0$ & $100 \pm 0$ \\
$0.50 \mathrm{mM}$ & $100 \pm 0$ & $61 \pm 4$ & $100 \pm 0$ \\
$0.25 \mathrm{mM}$ & $71 \pm 0$ & $31 \pm 4$ & $100 \pm 0$ \\
$0.10 \mathrm{mM}$ & $24 \pm 4$ & $\mathrm{ND}$ & $76 \pm 3$ \\
$0.05 \mathrm{mM}$ & $100 \pm 0$ & $100 \pm 0$ & $100 \pm 0$ \\
\hline 7-Methoxycamalexin (11) & $80 \pm 0$ & $100 \pm 0$ & $100 \pm 0$ \\
$0.50 \mathrm{mM}$ & $30 \pm 4$ & $40 \pm 2$ & $62 \pm 3$ \\
$0.25 \mathrm{mM}$ & $\mathrm{ND}$ & $17 \pm 4$ & $38 \pm 3$ \\
$0.10 \mathrm{mM}$ & & & \\
$0.05 \mathrm{mM}$ & $59 \pm 3$ & $88 \pm 3$ & $100 \pm 0$ \\
\hline $6,7-\mathrm{Dimethoxycamalexin} \mathrm{(12)}$ & $49 \pm 4$ & $62 \pm 3$ & $74 \pm 4$ \\
$0.50 \mathrm{mM}$ & $14 \pm 3$ & $21 \pm 3$ & $44 \pm 3$ \\
$0.25 \mathrm{mM}$ & & & \\
$0.10 \mathrm{mM}$ & & & \\
\hline
\end{tabular}

a Percentage of growth inhibition calculated using the formula: \% inhibition $=100-$ [(growth on amended/growth in control) $x$ 100]; values represent the mean and standard deviation of two independent experiments conducted in triplicate; ND=not determined. 


\section{Discussion}

To the best of our knowledge this is the first report of the occurrence and isolation of 7methoxycamalexin (11) and 6,7-dimethoxycamalexin (12) from a natural source, although both compounds have been previously obtained by chemical syntheses (Pedras and Abdoli, 2018). The antifungal activity of these new natural products indicates that they function as phytoalexins in $N$. paniculata. Camalexins 9 and 10 were isolated for the first time in 1991 from C. sativa and later on camalexin (9) was reported as a phytoalexin of A. thaliana, C. bursa-pastoris and Arabis lyrata L., all species belonging to the tribe Camelineae (Pedras et al., 2011). Curiously, due to the research impact of the model plant $A$. thaliana, camalexin (9) benefits from the highest popularity among the ca. 60 cruciferous phytoalexins reported to date (Pedras and Abdoli, 2017; Pedras et al., 2019; Pedras and Alavi, 2020). This popularity is reflected in the number of publications, with more than 440 articles retrieved through the SciFinder database (accessed March 2021 using the keyword "camalexin"). Importantly, camalexin (9) is resistant to degradation by some economically important fungal pathogens such as L. maculans, the causative agent of blackleg disease. Furthermore, we established that the rates of detoxification of camalexin by $A$. brassicicola and Botrytis cinerea (Pers. Fr., teleomorph Botryotinia fuckeliana (de Bary) Whetzel) (6-8 days vs. $12 \mathrm{~h}$, respectively), correlated with the susceptibility and resistance of $A$. thaliana (accession Columbia) to each pathogen (Pedras and Abdoli, 2017). As well, molecular genetics studies have reported that an $A B C$ transporter mediating the secretion of camalexin (9) from the epidermal cells to the surface of leaves confers resistance to $A$. brassicicola infection (Khare et al., 2017). Considering that intertribal hybrids between C. sativa and Brassica oleracea L. showed a high level of resistance to A. brassicicola and that this resistance was correlated with the induction of high concentrations of camalexin (susceptible hybrids produced lower amounts of camalexin) (Sigareva and Earle, 1999), we suggest that $N$. paniculata could be exploited to generate hybrid plants resistant to L. maculans, i.e., blackleg disease. By contrast to camalexins, the impact of 3-indole carboxylate (13) on plant defense programs has not been established, although it appears to be a likely a side product/artifact of the camalexin biosynthetic pathway (Mueller et al., 2019).

Previously, arabidopsides A, C, D, and the oxylipin 12-oxophytodienoic acid together with the phytoalexin erucalexin were isolated from abiotically elicited Erucastrum canariense Webb \& Berthel (Brassicaceae, tribe Brassiceae) (Pedras and To, 2017). Importantly, it was demonstrated that wounding induced arabidopsides but not erucalexin. Furthermore, arabidopsides $A$ and $D$ together with the phytoalexins nasturlexins and cyclonasturlexin were isolated from elicited leaves of Nasturtium officinale R. Br. (Brassicaceae, tribe Cardamineae) (Pedras and To, 2016, 2017). Arabidopsides are galacto-oxylipins, i.e., glycosylated phytooxylipins that contain at least one galactose unit and appear to have a much more restricted distribution than phytooxylipins (Dave and Graham, 2012). Phytooxylipins, 
a widespread class of lipids, are precursors of signaling molecules and result from lipoxygenase oxidation of unsaturated fatty acids such as linoleic acid (18:2), $\alpha$-linolenic acid (18:3), and hexadecatrienoic acid (16:3). In general, galacto-oxylipins are involved in signal transduction and cell communication related to plant responses to biotic stress such as pathogen attack (Siebers et al., 2016; Ibrahim et al., 2011). It is somewhat surprising to realize that the apparently synchronized biosynthesis of phytoalexins and galacto-oxylipins has only been reported in E. canariense and $N$. officinale (Pedras and To, 2017) and now in N. paniculata, although several galacto-oxylipins have been detected in Brassicaceae species including N. paniculata (Böttcher, 2007; Böttcher and Pollmann, 2009; Hartley et al., 2015; Hou et al., 2016; Genva et al., 2019).

\section{Conclusion}

The fact that camalexins have only been reported in plant species that belong to the tribe Camelineae (family Brassicaceae) is consistent with our hypothesis that Brassicales species grouped in the same tribe biosynthesize structurally similar phytoalexins. Based on the work reported above and since L. maculans is unable to detoxify camalexins, production of hybrids between $N$. paniculata and Brassica species appears to be a rational strategy to generate plants resistant to blackleg disease (caused by L. maculans), one of the most damaging fungal diseases of canola crops.

To the best of our knowledge, this report presents the third example of synchronized biosynthesis of phytoalexins and galacto-oxylipins in abiotically stressed plants and suggests that galacto-oxylipins structurally similar to arabidopsides are likely to occur in a much larger number of species than previously hypothesized. 


\section{Experimental}

\subsection{General}

All solvents were HPLC grade and used as such; unless otherwise noted, materials were obtained from commercial suppliers and used without further purification. Flash column chromatography (FCC) was carried out using silica gel grade 60, mesh size $230-400 \AA$ or RP $\mathrm{C}_{18}$ prepscale bulk packing $275 \AA$ A (J.T. Baker, NJ, USA). Organic extracts were dried over $\mathrm{Na}_{2} \mathrm{SO}_{4}$ and solvents were removed using a rotary evaporator.

NMR spectra were recorded on Bruker Avance spectrometers; for ${ }^{1} \mathrm{H}$ NMR (500 or $600 \mathrm{MHz}$ ) and ${ }^{13} \mathrm{C}$ NMR (125.8 or $150.9 \mathrm{MHz}$ ) spectra, the chemical shifts $(\delta)$ are reported in parts per million (ppm) relative to TMS. MS data [high resolution (HR) were obtained on a Qstar XL MS/MS System (ESI) by LC or direct insertion.

FTIR spectra were obtained using a Bruker Tensor 27, resolution $2 \mathrm{~cm}^{-1}$; samples were prepared as a film on a $\mathrm{KBr}$ disk or pellet using dry $\mathrm{KBr}$ (IR grade).

\subsection{HPLC analyses}

HPLC-DAD analysis was carried out with Agilent 1100 and 1200 series systems equipped with quaternary pumps, autosamplers, diode array detectors (DAD, wavelength range 190-600 nm, bandwidth $4 \mathrm{~nm}$ ), degasser and a Zorbax Eclipse XDB-C18 column (5 $\mu \mathrm{m}$ particle size silica, $150 \times 4.6$ mm I.D.), equipped with an in-line filter. Method A: mobile phase $\mathrm{H}_{2} \mathrm{O}-\mathrm{CH}_{3} \mathrm{CN}$ from 75:25 to 25:75, linear gradient for $35 \mathrm{~min}$, and a flow rate of $1.0 \mathrm{~mL} / \mathrm{min}$. Detection and quantification of phytoalexins was carried out using method $A$ and calibration curves built for each purified metabolite $\left(r^{2} \geq 0.991\right)$.

HPLC-DAD-ESI-MS analysis was carried out with an Agilent 1100 series HPLC system equipped with an autosampler, binary pump, degasser, and a diode array detector connected directly to a mass detector (Agilent G2440A MSD-Trap-XCT ion trap mass spectrometer) with an electrospray ionization (ESI) source. Chromatographic separations were carried out at room temperature using an Eclipse XDB-C-18 column (5 $\mu \mathrm{m}$ particle size silica, $150 \mathrm{~mm} \times 4.6 \mathrm{~mm}$ I.D.). Method B: mobile phase $\mathrm{H}_{2} \mathrm{O}$ (with $0.2 \% \mathrm{HCO}_{2} \mathrm{H}$ ) $-\mathrm{CH}_{3} \mathrm{CN}$ (with $0.2 \% \mathrm{HCO}_{2} \mathrm{H}$ ) from 75:25 to 25:75 linear gradient for 25 min and a flow rate of $1.0 \mathrm{~mL} / \mathrm{min}$. Data acquisition was carried out in positive and negative polarity modes in a single LC run, and data processing carried out with Agilent Chemstation Software.

\subsection{Plant material and extractions}

Seeds of Neslia paniculata CN 105426 were obtained from Plant Gene Resources of Canada, 
AAFC, Saskatoon, SK. Due to very low germination rates in soil $(<10 \%)$, seeds were incubated in Petrie dishes lined with filter paper moistened with aq. $0.2 \% \mathrm{KNO}_{3}$, in the dark at $23 \pm 1{ }^{\circ} \mathrm{C}$. After 10 days, seedlings were planted in a perlite and nutrient free LG-3 soil (Sun Gro Horticulture Canada) in pots (15 $\mathrm{cm}$ diameter) in a growth chamber (16 $\mathrm{h}$ of light/8 $\mathrm{h}$ of dark). For elicitation of phytoalexins and timecourse analysis, 4-week-old plants were sprayed with a $\mathrm{CuCl}_{2}$ aq. solution (10 $\left.\mathrm{mM}\right)$, plants were kept in a growth chamber and leaves (ca. $2.0 \mathrm{~g}$ fresh weight per sample) were excised after 1, 3, 5 days after elicitation, were frozen in liq. $\mathrm{N}_{2}$, grounded and the resulting leaf materials were individually extracted with $\mathrm{MeOH}(10 \mathrm{~mL})$. The extracts were filtered, the filtrates were concentrated and rinsed with DCM. The DCM extracts were concentrated, dissolved in $\mathrm{CH}_{3} \mathrm{CN}-\mathrm{MeOH}(1: 1)$ and analyzed by HPLC-DAD using method A (Fig. 2) and by HPLC-DAD-ESI-MS using method B.

For isolation of the unknown metabolites detected in elicited extracts, a larger scale experiment was carried out and leaves (96 g fresh leaves, HPLC-DAD in Fig. S1) were frozen and ground in liq. $\mathrm{N}_{2}$ and then extracted as summarized in Fig. 3.

\section{4-Week-old plants (potted)}

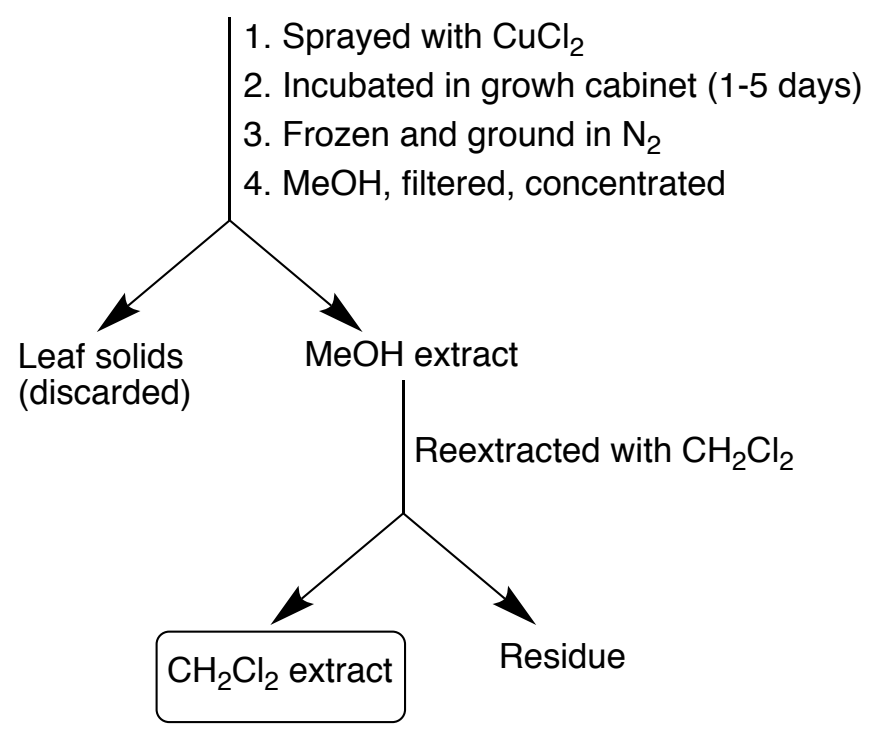

Fig. 3. Flow chart of extraction of metabolites from elicited leaves (96 $\mathrm{g}$ fresh weight) of Neslia paniculata (large-scale experiment).

\subsection{Isolation of metabolites}

The $\mathrm{CH}_{2} \mathrm{Cl}_{2}$ (DCM) extract obtained as described above was fractionated using both normal silica gel and reverse phase (RP-C ${ }_{18}$ ) silica (Fig. 4); the purified metabolites were characterized using 
spectroscopic analyses and structures confirmed by direct comparison with synthetic samples. Camalexins 9 and 11-12 were synthesized as previously reported (Pedras and Abdoli, 2018).

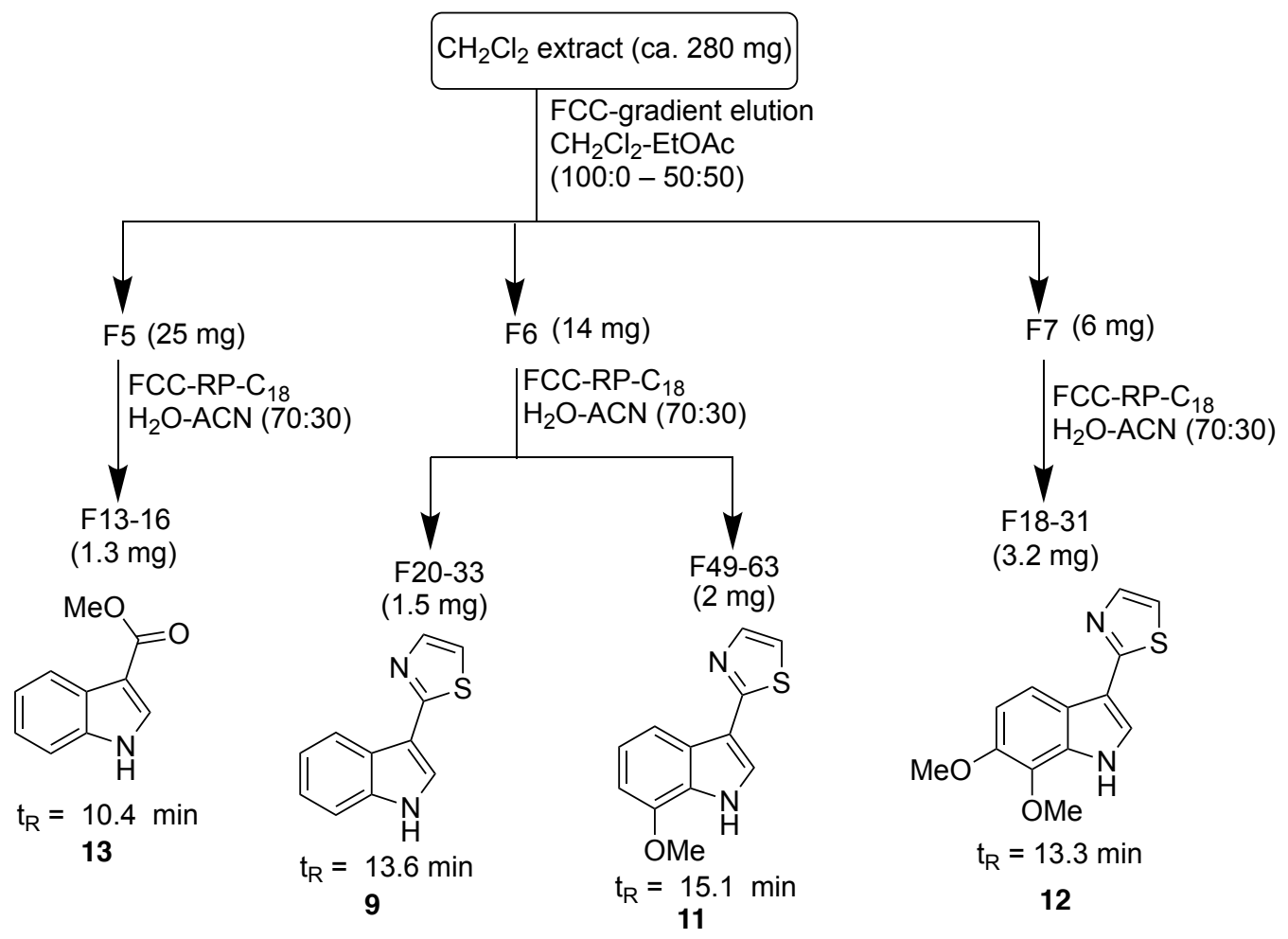

Fig. 4. Flow chart of isolation of elicited metabolites 9 and 11-13 from leaf extracts (280 mg) of Neslia paniculata.

\subsection{Antifungal bioassays}

The antifungal activity of metabolites was determined using a mycelial radial growth assay. Spore suspensions of $A$. brassicicola isolate UAMH 7474 and L. maculans isolate UAMH 9410, obtained from the University of Alberta Micro Fungus Collection and Herbarium, were pipetted onto potato dextrose agar plates (PDA) and incubated for seven days under constant light at $23 \pm 1{ }^{\circ} \mathrm{C}$. Sclerotia of S. sclerotiorum clone \#33, obtained from the AAFC Saskatoon Research Center, were placed on PDA plates and incubated for four days in the dark. Solutions of compounds $(0.50,0.25,0.10$ and $0.05 \mathrm{mM})$ in DMSO were prepared and suspended in PDA, transferred to wells of 12-well plates $(1.5 \mathrm{~mL}$ per well for PDA). Mycelial plugs (2 $\mathrm{mm}$ ) of each fungal species were cut from the edges of agar growing mycelia and placed inverted onto PDA at the center of each well. Control mycelia were grown on PDA containing only DMSO (1\% DMSO in PDA media). Plates were incubated under constant light or in darkness at 23 $\pm 1^{\circ} \mathrm{C}$, up to $100 \mathrm{~h}$; the diameters of the mycelia were measured $(A$. brassicicola, $60 \mathrm{~h}$ under continuous light; L. maculans, $90 \mathrm{~h}$ under continuous light; S. sclerotiorum, 12-15 $\mathrm{h}$ in the dark) and compared to control mycelia grown on plates containing only DMSO, using the formula: \% inhibition = $100-$ 
[(growth on amended/growth in control) $\times 100$ ]; values represent the mean and standard deviation of two independent experiments conducted in triplicate (Table 2).

\section{Acknowledgments}

Support for the authors' work was obtained from the Natural Sciences and Engineering Research Council of Canada (Discovery Research Grant to M.S.C.P.), and the University of Saskatchewan (CGSR graduate scholarship to M.A.). We thank the Plant Gene Resources Canada, AAFC, Saskatoon, SK, for donation of seeds, and acknowledge the technical assistance of K. Thoms in HR-ESI-MS determinations (Department of Chemistry and Saskatchewan Sciences Structural Centre).

\section{References}

Agerbirk, N., Olsen, C.E., 2012. Glucosinolate structures in evolution. Phytochemistry 77 16-45.

Ahmed, S., Kovinich, N. 2020. Regulation of phytoalexin biosynthesis for agriculture and human health. Phytochem Rev. https://doi.org/10.1007/s11101-020-09691-8.

Alavi, M. 2019. Elicited metabolites from Brassicaceae species and Tropaeolum majus: isolation, structure determination and antifungal activity. Ph.D. Thesis, University of Saskatchewan, SK.

Bailey, J.A., Mansfield, J.W., 1982. Phytoalexins. Blackie and Son, Glasgow, U.K., 334 pp.

Blazevic, I., Montaut, S., Burcul, F., Olsen, C.E., Burow, M., Rollin, P., Agerbirk, N. 2020. Glucosinolate structural diversity, identification, chemical synthesis and metabolism in plants. Phytochemistry 169, 112100.

Böttcher C. 2007. Studies on the biology of free and esterified phytodienoic acids. Doctoral thesis, Ruhr-University Bochum, Germany.

Böttcher, C., Pollmann, S., 2009. Plant oxylipins: Plant responses to 12-oxo-phytodienoic acid are governed by its specific structural and functional properties. FEBS J. 276, 4693-4704.

Czerniawski, P., Piasecka, A., Bednarek, P. 2021. Evolutionary changes in the glucosinolate biosynthetic capacity in species representing Capsella, Camelina and Neslia genera. Phytochemistry 181, 112571.

Dave, A., Graham, I.A., 2012. Oxylipin signaling: A distinct role for the jasmonic acid precursor cis-(+)12-oxo-phytodienoic acid (cis-OPDA). Front. Plant Sci. 3, 42.

Francis, A., Warwick, S.I. 2003. The biology of Canadian weeds. 120. Neslia paniculata (L.) Desv. Can. J. Plant Sci. 83, 441-451.

Genva, M., Obounou Akong, F., Andersson, M.X., Deleu, M., Lins, L., Fauconnier, M.-L. 2019. New insights into the biosynthesis of esterified oxylipins and their involvement in plant defense and developmental mechanisms. Phytochem. Rev. 18, 343-358.

Hartley, S.E., Eschen, R., Horwood, J.M., Gange, A.C., Hill, E.M. 2015. Infection by a foliar endophyte elicits novel arabidopside-based plant defence reactions in its host, Cirsium arvense. New Phytol. 205, 816-827.

Hisamatsu, Y., Goto, N., Hasegawa, K., Shigemori, H. 2003. Arabidopsides A and B, two new 
oxylipins from Arabidopsis thaliana. Tetrahedron Lett. 44, 5553-5556.

Hisamatsu, Y., Goto, N., Sekiguchi, M., Hasegawa, K., Shigemori, H. 2005. Oxylipins Arabidopsides C and D from Arabidopsis thaliana. J. Nat. Prod. 68, 600-603.

Hou, Q., Ufer, G., Bartels, D., 2016. Lipid signalling in plant responses to abiotic stress. Plant Cell Environ. 39, 1029-1048.

Ibrahim, A., Schütz, A.-L., Galano, J.-M., Herrfurth, C., Feussner, K., Durand, T., Brodhun, F., Feussner, I., 2011. The alphabet of galactolipids in Arabidopsis thaliana. Front. Plant Sci. 2, 95.

Khare, D., Choi, H., Huh, S.U., Bassin, B., Kim, J., Enrico Martinoia, E., Sohn, K.H., Paek, K.-H., Lee, Y. 2017. Arabidopsis ABCG34 contributes to defense against necrotrophic pathogens by mediating the secretion of camalexin. Proc. Natl. Acad. Sci. USA 11, 114 E5712-E5720.

Kjaer, A., Schuster, A. 1972. Glucosinolates in seeds of Neslia paniculata. Phytochemistry 11, 30453048.

Kúc, J., 1995. Phytoalexins, stress metabolism, and disease resistance in plants. Annu. Rev. Phytopathol. 33, 275-297.

Mueller, T.M., Boettcher, C., Glawischnig, E. 2019. Dissection of the network of indolic defence compounds in Arabidopsis thaliana by multiple mutant analysis. Phytochemistry 161, 11-20.

Pastorczyk, M., Bednarek, P. 2016. The function of glucosinolates and related metabolites in plant innate immunity. in Advances in Botanical Research, Vol. 80, ed. S. Kopriva, Amsterdam: Elsevier Ltd., 171-198.

Pedras, M.S.C., Abdoli, A. 2017. Pathogen inactivation of cruciferous phytoalexins: detoxification reactions, enzymes and inhibitors. RSC Adv. 7, 23633-23646.

Pedras, M.S.C., Abdoli, A. 2018. Methoxycamalexins and related compounds: Syntheses, antifungal activity and inhibition of brassinin oxidase. Bioorg. Med. Chem. 26, 4461-4469.

Pedras, M.S.C., Abdoli, A., To, Q.H., Thapa, C. 2019. The ecological roles of tryptanthrin, indirubin and $N$-formylanthranilic acid in Isatis indigotica: phytoalexins or phytoanticipins? Chem. Biodivers. 16, e1800579.

Pedras, M.S.C., Alavi, A. 2020. Expanding the phytoalexin chemical space: Tropalexins A and B from Tropaeolum majus suggest evolutionary conservation of biosynthetic enzymes. ChemRxiv. Preprint. https://doi.org/10.26434/chemrxiv.13350335.v1

Pedras, M.S.C., Alavi, M., To, Q.H. 2015. Expanding the nasturlexin family: nasturlexins C and D and their sulfoxides are phytoalexins of the crucifers Barbarea vulgaris and $B$. verna. Phytochemistry 118, 131-138.

Pedras, M.S.C., To, Q.H. 2015. Non-indolyl cruciferous phytoalexins: Nasturlexins and tridentatols, a striking convergent evolution of defenses in terrestrial plants and marine animals? Phytochemistry 113, 57-63.

Pedras, M.S.C., To, Q.H., 2016. Unveiling the first indole-fused thiazepine: structure, synthesis and biosynthesis of cyclonasturlexin, a remarkable cruciferous phytoalexin. Chem. Commun. 52, 5880-5883.

Pedras, M.S.C., To, Q.H. 2017. Defense and signalling metabolites of the crucifer Erucastrum canariense: synchronized abiotic induction of phytoalexins and galacto-oxylipins. Phytochemistry 139, 18-24.

Pedras, M.S.C., Yaya, E.E., Glawischnig, E. 2011. The phytoalexins from cultivated and wild crucifers: Chemistry and biology. Nat. Prod. Rep. 28, 1381-1405. 
Siebers, M., Brands, M., Wewer, V., Duan, Y., Hölzl, G., Dörmann, P., 2016. Lipids in plant-microbe interactions. Biochim. Biophys. Acta - Mol. Cell Biol. Lipids 1861, 1379-1395.

Sigareva, M.A., Earle, E.D. 1999. Camalexin induction in intertribal somatic hybrids between Camelina sativa and rapid-cycling Brassica oleracea. Theor. Appl. Gen. 98,164-170.

Tewari, J.P., Conn, K.L. 1993. Reactions of some wild crucifers to Alternaria brassicae. Bull. OILB SROP (France) 16, 53-58.

VanEtten, H.D., Mansfield, J.W., Bailey, J.A., Farmer, E.E., 1994. Two classes of plant antibiotics: Phytoalexins versus "phytoanticipins." Plant Cell 6, 1191-1192.

Windsor, A.J., Reichelt, M., Figuth, A., Svatos, A., Kroymann, J., Kliebenstein, D.J., Gershenzon, J., Mitchell-Olds, T. 2005. Geographic and evolutionary diversification of glucosinolates among near relatives of Arabidopsis thaliana (Brassicaceae). Phytochemistry 66, 1321-1333. 
Phytoalexins and signalling metabolites

\section{Supplementary Information}

\section{Experimental-SI}

HPLC-DAD chromatogram of leaf extracts of large-scale experiment

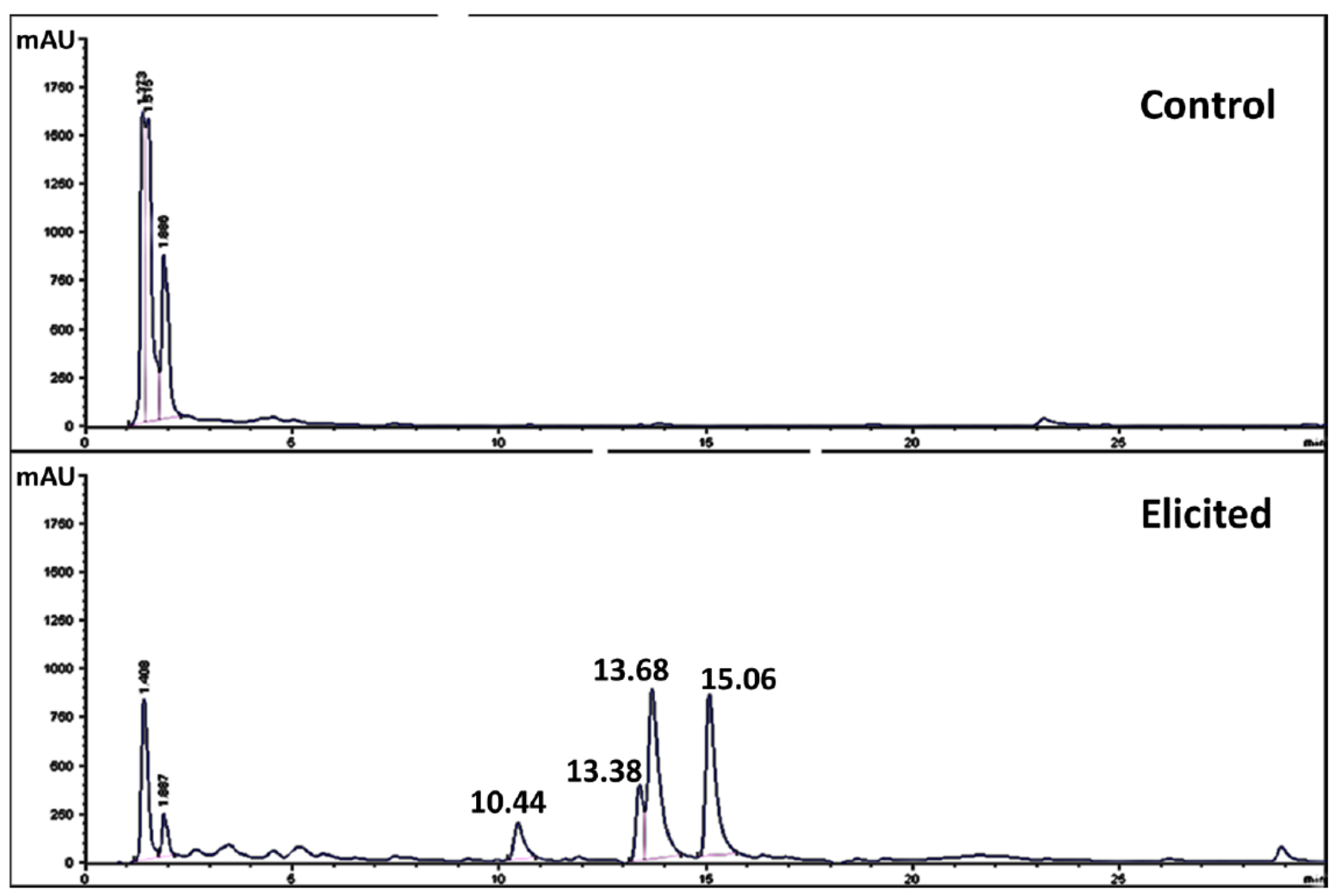

Fig. S1. Chromatogram of extracts of large-scale experiment (96 $\mathrm{g}$ fresh leaves) used to extract metabolites from elicited and control leaves ( $24 \mathrm{~h}$ post elicitation) of Neslia paniculata. 
HPLC-UV absorption spectra of arabidopsides $A(14)$ and $D(15)$ and compound at $t_{R}=33.4$ $\min$.
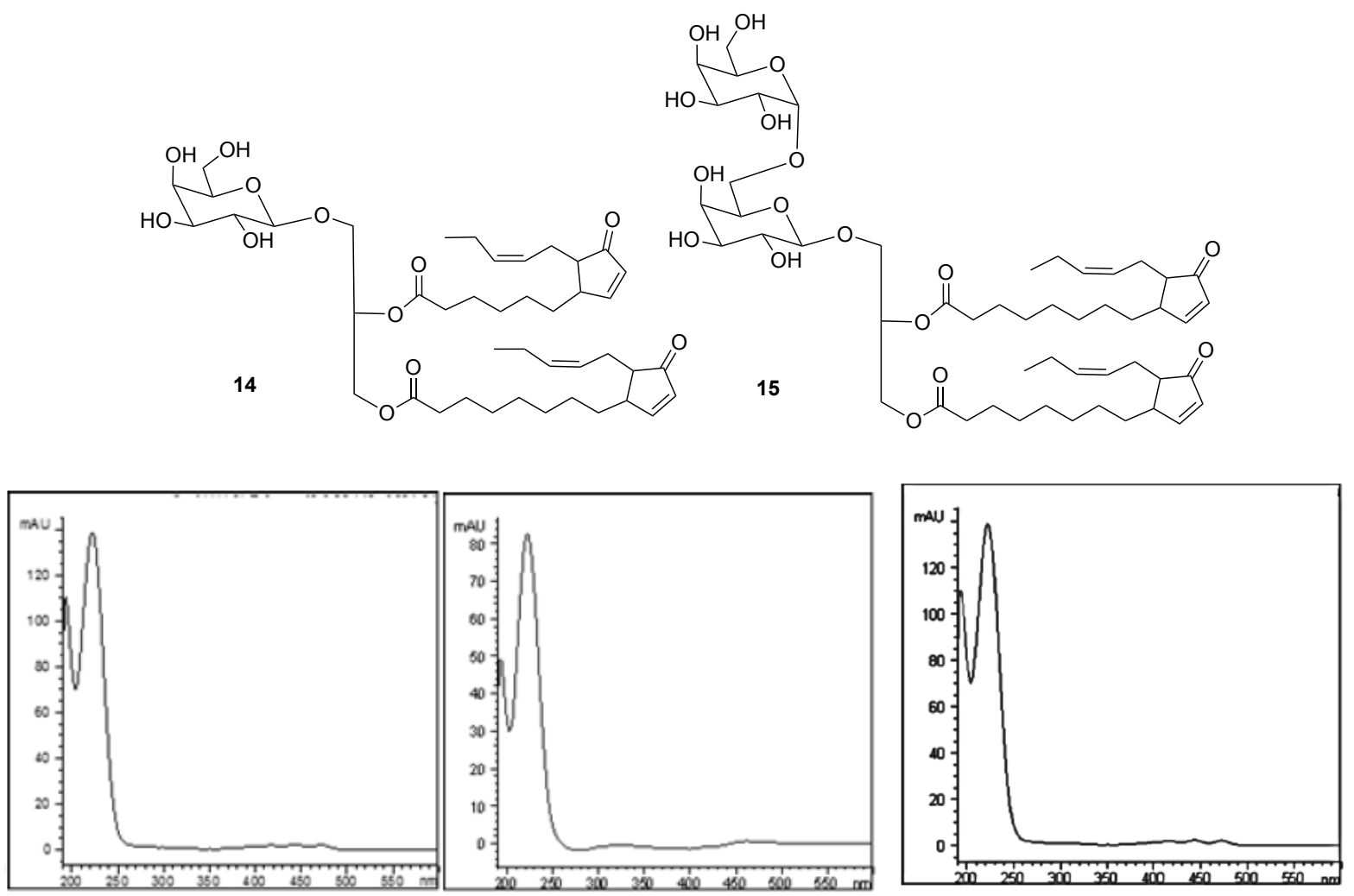

Fig. S2. HPLC-UV absorption spectra of arabidopsides $A(14)$ and $D(15)$ and compound at $t_{R}=33.4$ $\min$.

\section{Spectroscopic characterization new natural products 11 and 12}

\section{7-Methoxycamalexin (11)}

$t_{R}=15.1 \min ($ HPLC method $A)$.

${ }^{1} \mathrm{H}$ NMR $\left(500 \mathrm{MHz}, \mathrm{CD}_{3} \mathrm{CN}\right): \delta 9.82(1 \mathrm{H}, \mathrm{brs}), 7.86(1 \mathrm{H}, \mathrm{d}, J=2.5 \mathrm{~Hz}), 7.80(1 \mathrm{H}, \mathrm{d}, J=8 \mathrm{~Hz}), 7.77(1 \mathrm{H}$, d, $J=3.5 \mathrm{~Hz}), 7.35(1 \mathrm{H}, \mathrm{d}, J=3.5 \mathrm{~Hz}), 7.17(1 \mathrm{H}, \mathrm{dd}, J=8,8 \mathrm{~Hz}), 6.79(1 \mathrm{H}, \mathrm{d}, J=8 \mathrm{~Hz}), 3.97(3 \mathrm{H}, \mathrm{s})$. ${ }^{13} \mathrm{C}$ NMR $\left(150 \mathrm{MHz}, \mathrm{CDCl}_{3}\right): \delta 163.5,146.4,142.7,127.2,126.1,124.0,122.1,116.1,113.3,113.2$, 103.1, 55.6.

HPLC UV (HPLC, $\left.\mathrm{CH}_{3} \mathrm{CN}-\mathrm{H}_{2} \mathrm{O}\right) \lambda_{\max }(\mathrm{nm}): 220,250,320$.

FTIR (KBr) $v_{\max }: 3120,1624,1578,1543,1249 \mathrm{~cm}^{-1}$.

HR-El-MS m/z (\%): calc. for $\mathrm{C}_{12} \mathrm{H}_{10} \mathrm{~N}_{2} \mathrm{OS}$ : 230.0513 , found 230.0509 (100). 


\section{7-Methoxycamalexin}

${ }^{1} \mathrm{H} \mathrm{NMR}\left(500 \mathrm{MHz}, \mathrm{CD}_{3} \mathrm{CN}\right)$

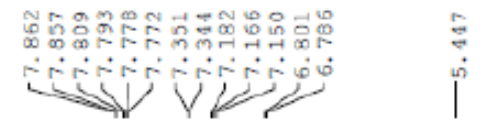

1

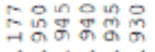

نंiviji

1

$\mathrm{MHz}, \mathrm{CD}_{3} \mathrm{CN}$ )<smiles>COc1cccc2c(-c3nccs3)c[nH]c12</smiles>
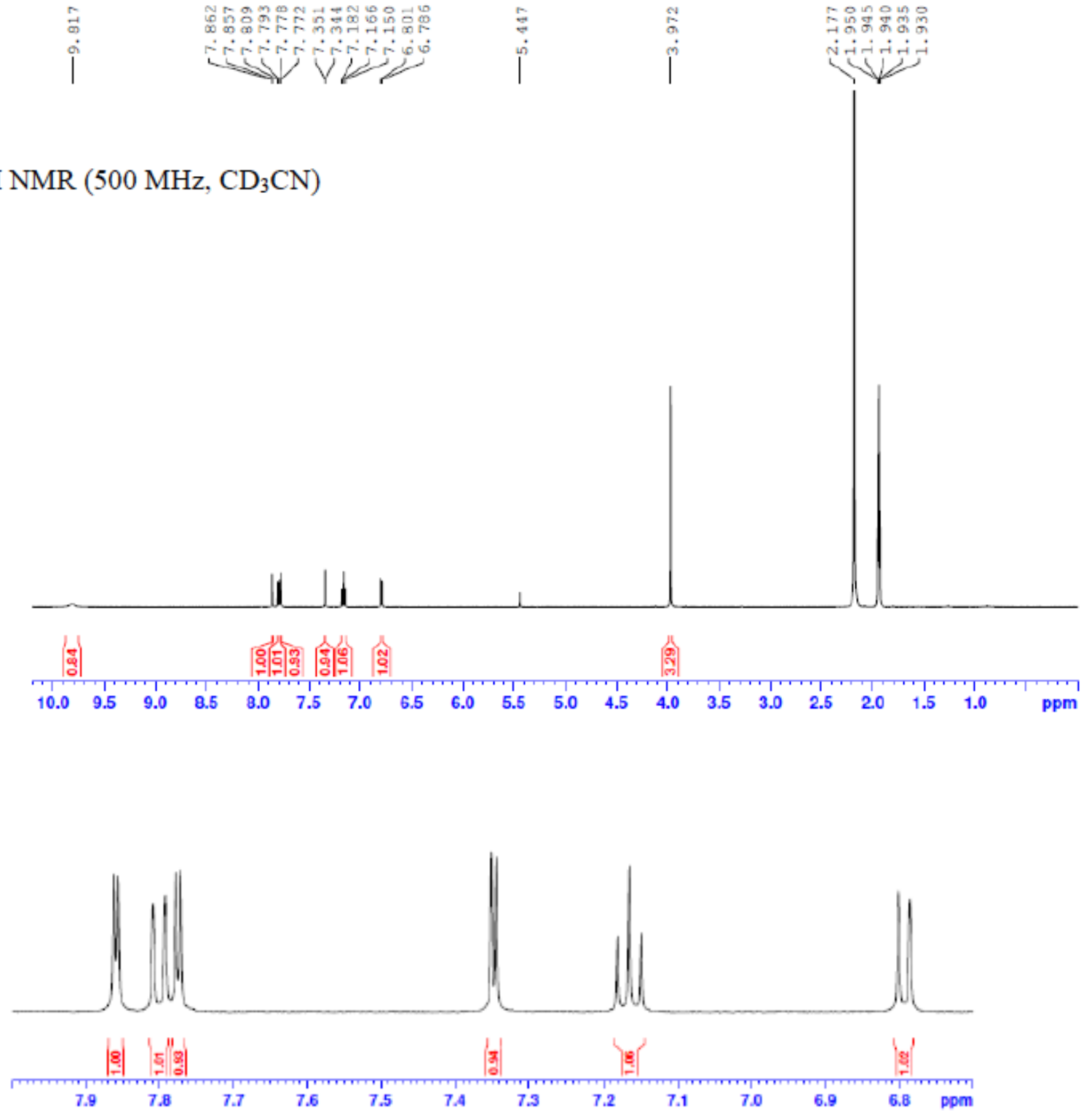
Pedras et al.

Phytoalexins and signalling metabolites

${ }^{13} \mathrm{C}$ NMR (150 MHz, $\mathrm{CDCl}_{3}$ )

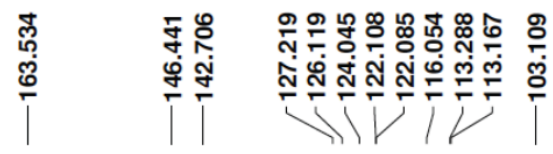

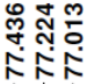

|ొ

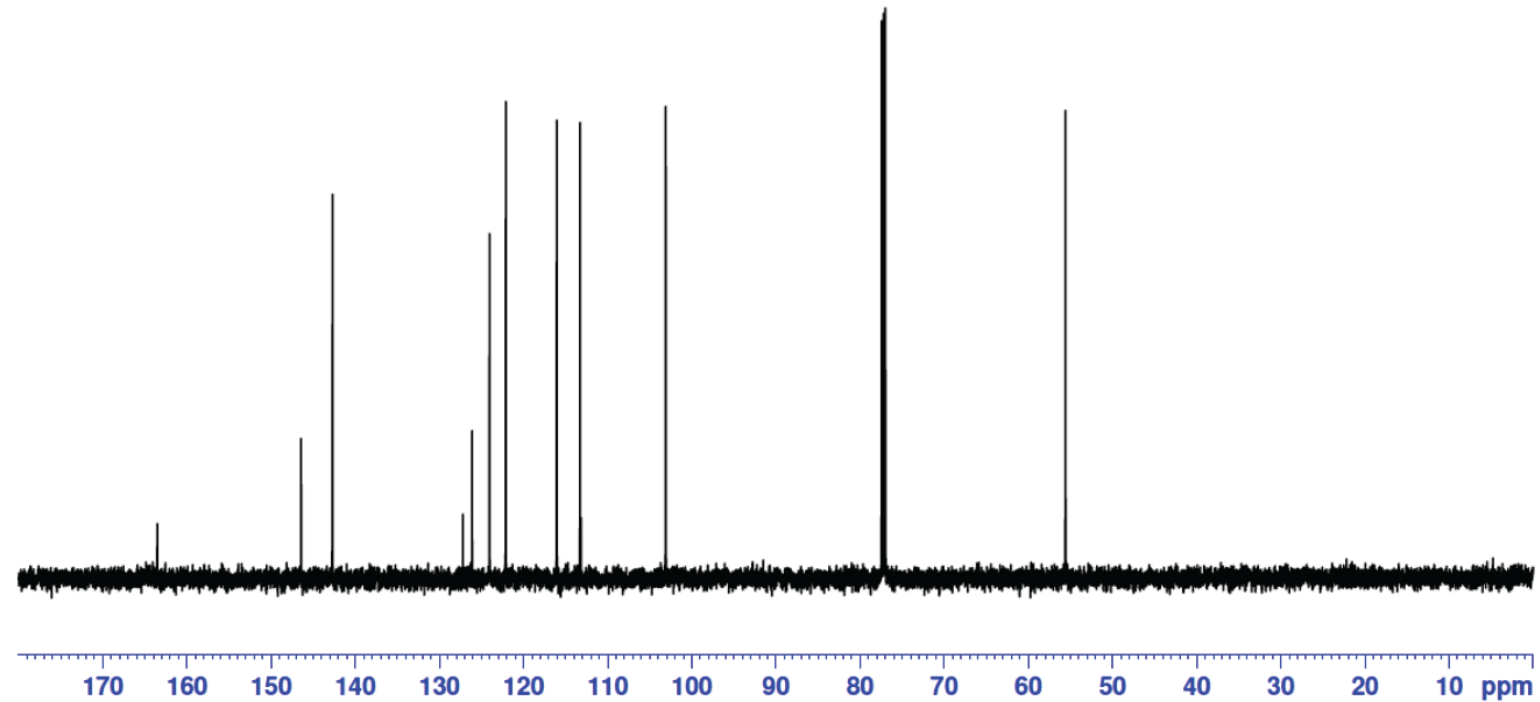

Bio-Rad Win-IR

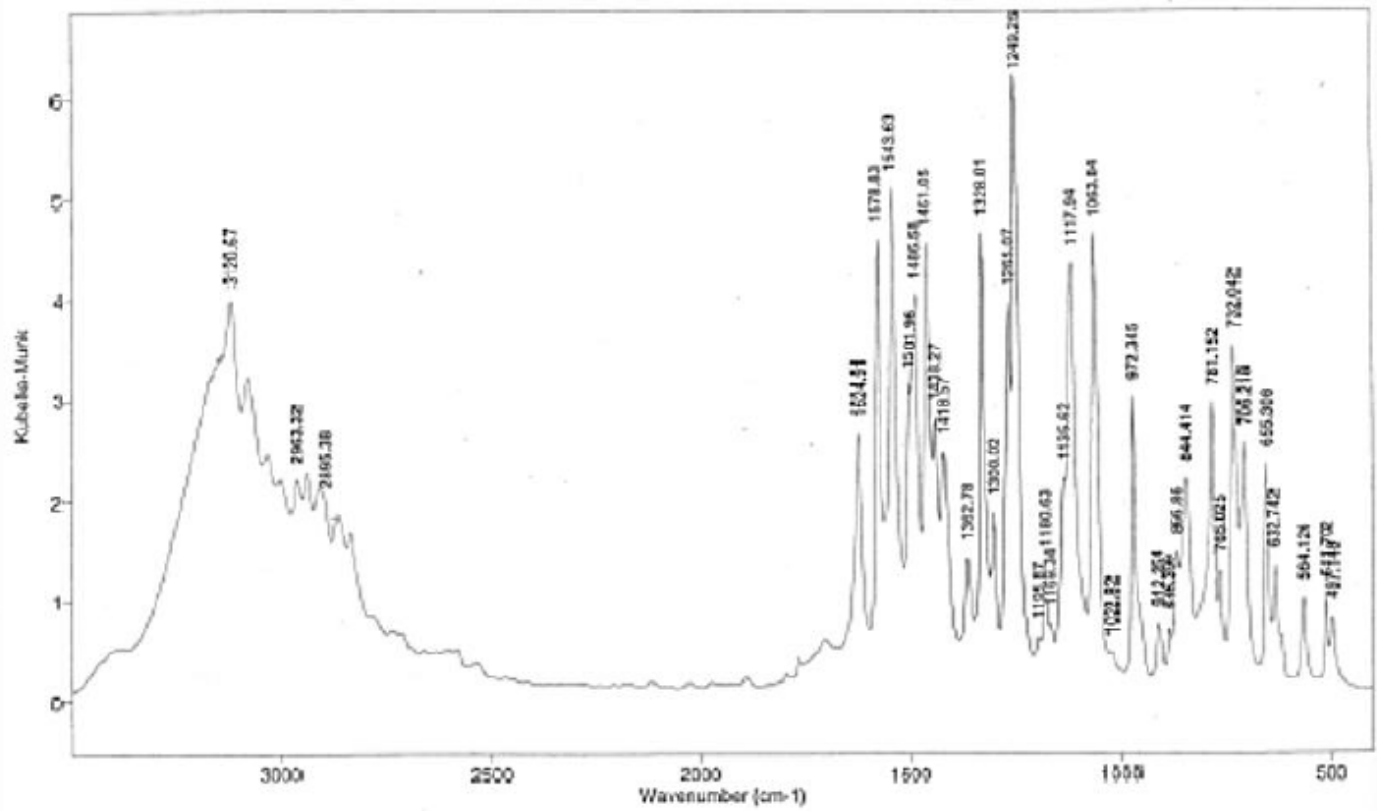




\section{6,7-Dimethoxycamalexin (12)}

HPLC $t_{R}=13.4$ min (HPLC method A).

${ }^{1} \mathrm{H}$ NMR $\left(500 \mathrm{MHz}, \mathrm{CD}_{3} \mathrm{CN}\right): \delta 9.73(1 \mathrm{H}, \mathrm{brs}), 7.87(1 \mathrm{H}, \mathrm{d}, J=8.5 \mathrm{~Hz}), 7.82(1 \mathrm{H}, \mathrm{brs}), 7.76(1 \mathrm{H}, \mathrm{d}, J=$ $3 \mathrm{~Hz}), 7.33(1 \mathrm{H}, \mathrm{d}, J=3 \mathrm{~Hz}), 7.03(1 \mathrm{H}, \mathrm{d}, J=8.5 \mathrm{~Hz}), 3.94(3 \mathrm{H}, \mathrm{s}), 3.90(3 \mathrm{H}, \mathrm{s})$.

${ }^{13} \mathrm{C}$ NMR $\left(150 \mathrm{MHz}, \mathrm{CDCl}_{3}\right): \delta 163.4,147.9,142.8,134.7,131.3,124.2,121.2,116.0,115.8,113.1$, 110.0, 61.3, 57.5.

UV (HPLC, $\left.\mathrm{CH}_{3} \mathrm{CN}-\mathrm{H}_{2} \mathrm{O}\right) \lambda_{\max }(\mathrm{nm}): 210,250,290,330$.

FTIR (KBr) $\nu_{\max }: 3116,1632,1513,1240,1086 \mathrm{~cm}^{-1}$.

HR-El-MS m/z (\%): calc. for $\mathrm{C}_{13} \mathrm{H}_{12} \mathrm{~N}_{2} \mathrm{O}_{2} \mathrm{~S}: 260.0619$, found 260.0612 (100).<smiles>COc1ccc2c(-c3nccs3)c[nH]c2c1OC</smiles>

\section{6,7-Dimethoxycamalexin}

${ }^{1} \mathrm{H} \mathrm{NMR}\left(500 \mathrm{MHz}, \mathrm{CD}_{3} \mathrm{CN}\right)$

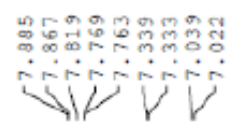

\section{$\stackrel{5}{\mathfrak{j}}$}

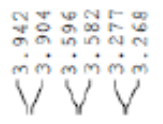




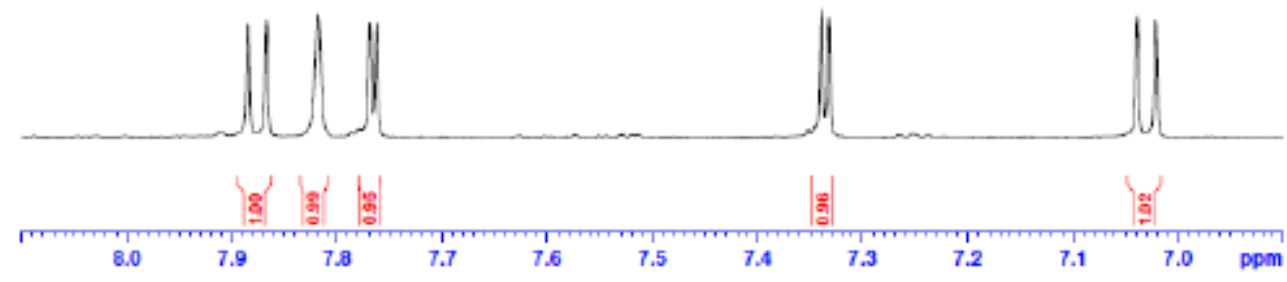

${ }^{13} \mathrm{C}$ NMR (150 MHz, $\left.\mathrm{CDCl}_{3}\right)$

l |

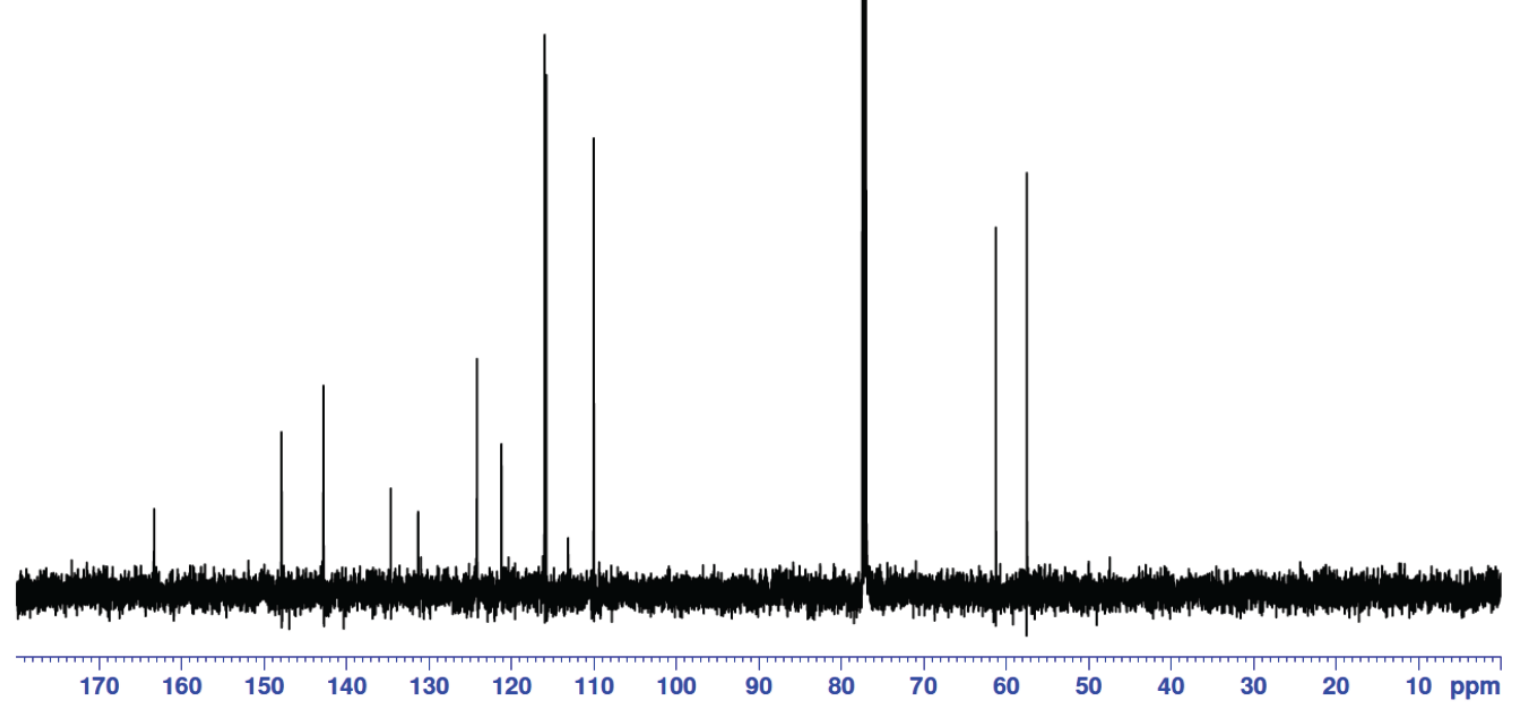


Phytoalexins and signalling metabolites

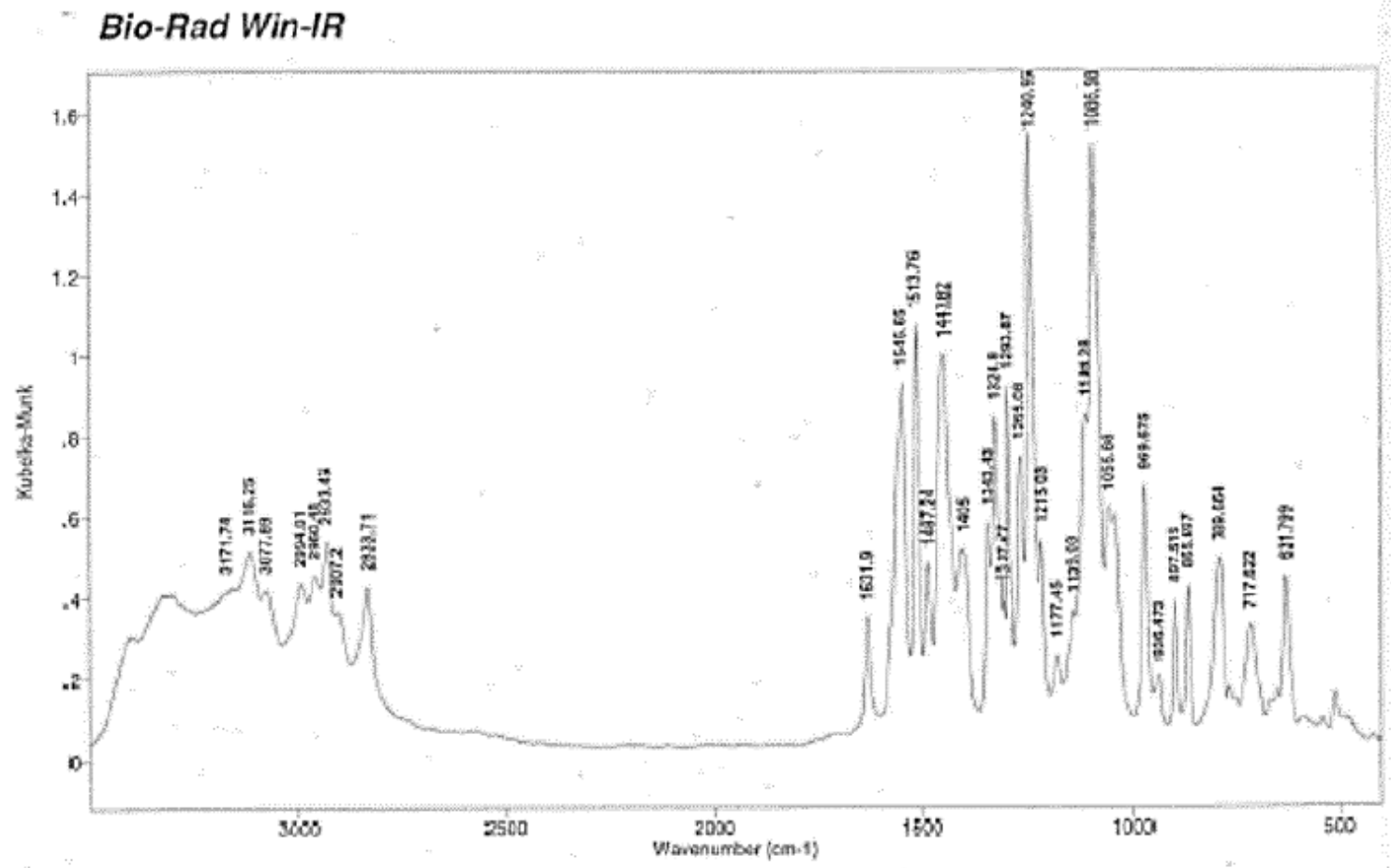

